\title{
KRITIK AF MARX'S \\ TINGSLIGGØRELSESTEORI
}

\author{
Anders Lundkvist
}

\section{Indledning}

Marx's kapitalismekritik kan opdeles i et kvantitativt aspekt, nemlig udbytnings- eller merværditeorien, og et kvalitativt aspekt, tingsliggørelsesteorien, hvorom denne artikel vil handle.

Marx's hovedtanke er at de sociale forhold i det borgerlige samfund fremtraeder tingsligt. Kapitalismens grundlov er værdiloven, dvs. værdiens styring af de økonomiske sammenhænge, men således ser det ikke ud: Værdien er et socialt fænomen, dvs. det indeholder 'ikke ét atom naturstof', ${ }^{1}$ men når den fremtræder i de $\varnothing$ konomiske kategorier, antager den en tingslig form; derfor synes det som om samfundet og $\varnothing$ konomien styres af tingslige magter. Denne fordrejning skærpes i takt med kategoriernes konkretisering: I varen fremtræder værdien i form af egenskaber ved ting, ved penge i form af en ting, og ved kapitalen som ting, der bliver til flere ting.

Er denne tingsliggørelse reel eller er den ren illusion? er fordrejningen virkelig eller blot bevidsthedsmæssig? Dette er nok de første spørgsmål, som læseren af 'Kapitalen' stiller. Marx's parallellisering til religionen, såvel som hans alternative betegnelse for tingsliggørelsen, nemlig fetichisme, kan forlede til den opfattelse at fordrejningen blot er en falsk bevidsthedsform, men der er ingen tvivl om at værdiformerne iflg. Marx er tingslige såvel reelt som for bevidstheden. Dette fremgår særlig klart af pengefetichismen, hvor Marx's pointe ikke er at folk fejlagtigt tror at penge er en ting (guld): hans pointe er at de sociale

1. Marx: Das Kapital, Band I, MEW 23, p. 62; Rhodos-oversættelsen, p. 143. I det flg. angives de 3 Kapital-bind som K.I., K.II. og K.III., og ovennævnte henvisning vil fremtræde som K.I., p. $62 / 143$. 
forhold faktisk inkarneres i en ting, hvorfor fordrejningen er en 'prosaisk reel mystifikation'. ${ }^{2}$

I 'Kapitalens Bevidsthedsformer' fra 1972 og 'Introduktion til metoden i Kapitalen' fra 1973 sondrer jeg mellem tingsliggørelsen, der er den virkelige og fetichismen, der er den bevidsthedsmaessige fordrejning; sidstnævnte fordrejning skulle så bestå i at man alene opfattede (genspejlede) den tingslige fremtrædelsesform eller værdiformen, mens det sociale væsen eller værdien forblev skjult (undtagen for videnskabsmanden, der var udstyret med en særlig evne til kritisk genspejling). Denne teori beviser samtidig for lidt og for meget: Den viser for lidt, thi selve sondringen mellem virkelighed og bevidsthed gør virkeligheden åndløs og for så vist tingslig, hvorfor teorien i stedet for at forklare, blot reproducerer tingsliggørelsen/fetichismen. Og den viser for meget, fordi dens konsekvens er, at folk skulle leve i lykkelig uvidenhed om at de $\varnothing$ konomiske kategorier overhovedet har noget med de sociale sammenhænge at gøre (disse genspejles jo ikke); men ethvert barn, der har læst sin Anders And (specielt om strudsen der lægger pengeæg), véd jo udmærket at penge på en eller anden måde har sociale karakteristika. I det flg. anvendes betegnelserne 'fetichisme' og 'tingsliggørelse' derfor i flæng.

Tesen i denne artikel er at de magter, det styrer samfundet, nok er fremmede, upersonlige og objektive, men ikke fordi de er tingslige. Tværtimod; i min bog, 'Kritik af privatarbejdet. 1. Del: Simpel vareproduktion', der formentlig udkommer i løbet af efteråret, har jeg formuleret en alternativ fordrejningsteori, hvis kerne er at de sociale forhold fremtræder som adskilte fra de naturlige (og for så vidt tingslige) forhold, hvilket på åbenbar vis kommer til syne i den $\emptyset$ kologiske krise. ${ }^{3}$

Når Marx's tingsliggørelsesteori har vundet tiltro, trods sin vanskeligt tilgængelige karakter, beror det nok på to forhold:

a) Det er indlysende at de $\varnothing$ konomiske sammenhænge - markedslovene, profitmaximeringen - er objektive, for så vidt som de ikke beherskes af menneskene (subjekterne). Det samme gælder de egentlige naturlove, f.ex. tyngdeloven. Men det er naturligvis logisk fejlagtigt alene ud fra denne parallellitet at slutte, at de økonomiske sammenhænge fremtræder som naturlige/tingslige sammenhænge.

b) Forskellen mellem kommunisme og vareproduktion - og dermed det fordrejede ved varen - ligger i, at mens den kommunistiske produktionsmåde er underkastet en social planlægning og derfor indebærer en umiddelbar

2. Marx: Zur Kritik der politischen Ökonomie, MEW 13, p. 35; Rhodos-oversættelsen, p. 43. Henvisningen vil i det flg. fremtræde som Til Kritikken, p. 35/43.

3. Denne artikel bygger på kap. 9 ('Kritik af Marx’s vare- og pengeteori') i ovennævnte bog. 
socialisering af arbejdet, bygger vareproduktionen på privatarbejdet, dvs. en produktionsmåde der er karakteriseret ved at den enkeltes arbejde ikke på forhånd indgår i en social sammenhæng; denne sammenhæng etableres først i udvekslingen af arbejdsprodukterne, dvs. privatarbejdet socialiseres efterfølgende eller indirekte. Det er nu fristende at slutte, at det fordrejede ved vareformen ligger i at den indebærer et socialt forhold mellem ting (arbejdsprodukter). Men slutningen er forkert, thi enhver distribution af arbejdsprodukter er et socialt forhold mellem ting; dette er tilfældet hvad enten det drejer sig om røveri eller den feudale bondes afgift til godsejeren, om kommunismens planlagte distribution eller vareudvekslingens uplanlagte. Det fordrejede ved vareproduktion, det der adskiller den fra kommunisme, består ikke i det, udvekslingen er, nemlig et socialt forhold mellem ting, men i det produktionen ikke er, nemlig et socialt forhold mellem arbejder.

\section{Teoriens achilleshæle}

Fetichisme- eller tingsliggørelsesteorien intenderer - bl.a. - at forklare, hvorfor den borgerlige bevidsthed er tingsliggjort. Den første forudsætning for teoriens rigtighed er derfor, at den borgerlige bevidsthed faktisk opfatter vare, penge og kapital tingsligt. Dette spørgsmål kan afgøres på rent empirisk vis.

Uheldigvis for Marx's teori er det ikke vanskeligt at vise, at den borgerlige bevidsthed er alt andet end netop tingslig.

Dette er mest åbenbart for pengenes vedkommende, thi iflg. moderne borgerlig teori er penge en social konvention, baseret på noget så substansløst som tillid:

»Penge er en kunstig social konvention. Hvis et materiale af en eller anden grund begynder at blive brugt som penge, vil alle mennesker begynde at tillægge det værdi, selv hvis de skulle være afholdsfolk, vegetarianere eller uden tro på materialets indre nytte /intrinsic usefulness/. Så længe ting kan købes og sælges v.hj.a. et bestemt materiale / substance/ vil folk være tilfredse med at sælge og købe det. Paradox: penge accepteres, fordi de accepteres! (Paul A. Samuelsen: Economics, An introductory Analysis, 6. ed. 1964, p. 52).

»Papirlapperne er værdifulde, fordi enhver mener at de er det, og enhver mener at de er det, fordi de efter vedkommendes erfaring altid har været det. Penge er således sidste instans /at bottom/ en social konvention...« (Milton Friedman: artiklen 'Money' i Encyclopædia Britannica, 15. ed.).

Penge subjektiveres, ja åndeliggøres, hvilket er nogenlunde det modsatte af en tingsliggørelse. 
Marx's tese om den tingslige opfattelse af penge beror på, at han selv mener at penge må forankres i en ting (guld), og at papirsedler henter deres værdi fra de guldkvanta, de symboliserer. Hvis dette var rigtigt - men det betvivles nedenfor - ville det imidlertid indebære at almindelige mennesker skulle have et relativt godt kendskab til pengesystemet for at blive feticherede, thi da Marx trods alt ikke tilskriver folk illusioner om at pengenes magt afhænger af pengesedlens papirkvalitet, må han hævde at folk tankemæssigt til stadighed reducerer sedlerne til guldkvanta.

Lad os dernæst betragte den borgerlige opfattelse af, hvilke faktorer der bestemmer bytteforholdet, altså varens kvantitative side. Marx's kronvidner indenfor emnet 'umiddelbare fremtrædelsesformer' er de såkaldte vulgærøkonomer, hvor vi skulle være sikre på at finde fetichisme i renkultur; slår man imidlertid op i en hvilken som helst lærebog i borgerlig økonomi, vil man finde mange betragtninger over behovene og mange fors $\varnothing \mathrm{g}$ på at forklare bytteforholdene og priserne ud fra de subjektive, dvs. marginale behov, - men man vil lede forgæves efter forsøg på at udlede bytteforholdene af smørs, kanoners og diamanters tingslige egenskaber. ${ }^{4}$ Igen: Den borgerlige bevidsthed tingsliggør ikke de sociale relationer, den subjektiverer dem. Det er en gådefuld kendsgerning, at moderne marxistisk teori, ofte i samme sætning, kritiserer moderne borgerlig økonomi for subjektivisme og tingsliggørelse; det første kritikpunkt er det virkelige, det andet blot 'lip-service' til Marx's teori.

Situationen er meget mærkelig. Arbejdsværdilærens traditionelle og 'naturlige' modpol er den subjektive behovsteori; hvis arbejdsværdilæren er rigtig, er den subjektivistiske teori og de reale forhold, som den støtter sig til, ren overflade, der fordrejer - eller i hvert fald tilslører - de virkelige sammenhænge. At vise dette må være opgaven for arbejdsværdilærens fordrejningsteori. Men Marx opstiller en indviklet teori, der med jernhård logik skal vise, hvorfor den borgerlige bevidsthed nødvendigvis begriber de sociale relationer (værdien) tingsligt. Borgerlige $\varnothing$ konomer allierer sig måske med psykologer for at bestemme folks præferencekurver, men de kunne ikke drømme om - som Marx antyder ${ }^{5}$ - at engagere en kemiker til at finde en værdi eller bytteværdi, der skulle være indeholdt i en 'perle eller diamant'; da borgerlig teori således med sindsro kan melde hus forbi, er det forståeligt at den aldrig har set fetichismeteorien som en udfordring.

4. Det skal dog nævnes, at Marx nævner ét - ét - exempel på varefetichisme, idet Samuel Bailey i en iøvrigt skarpsindig kritik af ideen om en immanent værdi, altså en værdi der er apriori i forhold til bytteværdien, er kommet for skade at sige at 'værdi er en egenskab ved tingene'; jvf. K.I., pp. 97f/185 og Theorien 26.3., pp. 126f og 145.

5. K.I., p. $98 / 185$. 
Tingsliggørelsesteorien er mystisk; ligeså mystisk som hvis en astronom udformede en kompliceret teori, der tog sigte på at forklare, hvorfor menneskene nødvendigvis umiddelbart tror at solen drejer rundt om Mars.

- Nu kan man naturligvis tage et extra skridt ud i tågen ved at hævde at de borgerlige $\varnothing$ konomers manglende fetichisme beror på at de har mystificeret den virkelige mysticisme: Måske tog Marx blot fejl mht. den teoretiske borgerlige bevidsthed, mens de byttende selv, altså den umiddelbare praktiske bevidsthed, begriber varen tingsligt?

Imidlertid er det vanskeligt at se, hvad der skulle få de byttende til at begribe deres sociale relationer som udsprunget af de ting, de bytter. Marx understreger andetsteds (end i fetichismediskussionen), at mens kapitalens telos er penge (evt. værdi, merværdi), er telos i det simple bytte og den enkle cirkulation brugsvardi. Skomageren bytter med skrædderen for at tilfredsstille sit behov for frakker, og hans klare interesse er at få flest mulige frakker for en given mængde sko; da skrædderen har den modsatte interesse, bestemmes bytteforholdet af styrkeforholdet mellem de to interesser, - et styrkeforhold, der især afhænger af intensiteten af behovene. Hvad enten bytteforholdet er fjernstyret af en skjult værdi eller ej, så er det umiddelbart bestemt af forholdet mellem frakkernes brugsværdi for skomageren og skoenes brugsværdi for skradderen.

De byttende er praktiske folk, de interesserer sig ikke for tingene af hensyn til tingene, men af hensyn til dem selv, dvs. de interesserer sig for deres nytte. Den umiddelbare bevidsthed er et redskab for den umiddelbare interesse; derfor er skomageren nødt til at focusere sine tanker på frakkens betydning for ham, tingen for ham, og det forekommer ikke sandsynligt at han får tid til at henfalde til en kantiansk grublen over tingen 'i sig selv'. Og selv hvis et filosofisk gemyt skulle have fået den tanke, at bytteforholdet netop er ét par sko for én frakke p.gr.a. visse tingslige egenskaber ved sko og frakker, falsificeres denne tese ugen efter, hvor bytteforholdet måske er skiftet til ét par sko for 2 frakker. Som Marx skriver:

»Bytteværdien fremtræder i første omgang som det kvantitative forhold eller som den proportion, i hvilken brugsværdier af én slags udveksler sig med brugsværdier af en anden slags, - et forhold, der bestandig skifter med tid og sted. Bytteværdien synes derfor at være noget tilfældigt og helt relativt, ...«(K.I., p. 50/129).

Hvis de byttende oplever bytteforholdet som bestemt af de tingslige egenskaber ved varerne, må de altså for det første være filosoffer, og for det andet dårlige filosoffer, thi det forhold, at de samme ting byttes i forskellige proportioner, alt efter tid og sted, må vel betyde at bytteforholdet ikke er bestemt af tingene som sådan. 
- Iflg. Marx udspringer tingsliggørelsen af vareformen, hvorfor den må være knyttet til alle varer. Imidlertid kan oplagt ikke-tingslige fænomener såsom know-how antage vareform; man kunne også nævne tjenesteydelser, hvor det er selve arbejdet der købes og sælges, eller rentekapitalen, thi iflg. Marx's teori giver rentekapitalisten selve kapitalfunktionen (udpresningen af merværdi) vareform, når han udlåner penge til industrikapitalisten. Ingen af disse varer kan være tingslig fremtrædelsesform for noget som helst. Det er en nødvendig betingelse for tingsliggørelsen, at der er en varekrop, en materialitetsform, som værdien kan spejle sig i eller projiceres over på, men denne forudsætning er ikke opfyldt for de ovenfor anførte varer; derfor kan varefetichismen højst gælde nogle varer, dvs. den kan ikke udspringe af vareformen, af varen som sådan.

Paradoxalt nok har man imidlertid i den marxistiske debat netop taget vareformens ubetvivlelige subsumtion af immaterielle fænomener under sig som et bevis på tingsliggørelsens udbredelse: det kan kaldes en fordrejning af fænomener som ære, samvittighed og viden købes og sælges som varer, men ikke tingsliggørelse. Ved således at sammenblande spørgsmålet om hvad varen er, med spørgsmålet om hvad der er vare, får man på sælsom vis forvandlet et empirisk materiale, der falsificerer Marx's teori, til en verifikation af denne.

Marx's fors $\varnothing \mathrm{g}$ på at subsumere de fordrejninger, han møder i fremstillingen, under fællesnævneren 'tingsliggørelse', støder på stigende vanskeligheder. Exempelvis: Hvis lønnen til sit væsen er en betaling for arbejdskraftens værdi (subsistensomkostningerne), så er lønformen, hvor det ubetvivleligt ser ud som om der betales for selve arbejdet, en fordrejet fremtrædelsesform; men hvorfor tale om lønfetichisme? hvorfor er det levende arbejde mere forstenet eller forbenet - for nu at bruge et par af Marx's alternative betegnelser for tingsligg ørelsen - end arbejdskraften? Dette er vanskeligt at se. Derimod er det let at se, at det er en fordrejning at menneskers arbejdskraft købes og sælges som var det et pund smør, dvs. en ting; og det er denne tankegang, der er realiteten i Lukács's og Marx’s? - udlægning af lønfetichismen: Varen er (normalt) et arbejdsprodukt, der (normalt) er en materiel ting; ${ }^{6}$ arbejdskraften antager vareform; ergo er lønformen udtryk for tingsligg ørelse. ${ }^{7}$ Måske, men dette har intet at gøre med Marx's begreb om fetichisme og tingsliggørelse.

6. Bemærk at fordi en vare er et arbejdsprodukt, er den ikke derfor nødvendigvis tingslig. Af de exempler på ikke-tingslige varer, der er givet ovenfor, er nogle arbejdsprodukter (tjenesteydelser, know-how (p.gr.a. uddannelsen)), andre ikke (ære, samvittighed, et medfødt sangtalent).

7. Dette ræsonnement findes selvfølgelig ikke explicit hos Lukács, men det skinner igennem i bemærkninger som: »Arbejdskraftens adskillelse fra arbejderens personlighed, dens forvandling til en ting, til en genstand /gegenstand/, som han sælger på markedet...« (Lukács: Geschichte und Klassenbewusstsein, Amsterdam 1967, p. 110; smlgn. pp. 98, 102, 111 og 112). I 'Marxismen i Frankrig' giver Peter Kemp en udmærket sammenfatning af Lukács's opfattelse, pp. 67-84 (Vinten 1979). 


\section{Marx's tingsliggørelse af de sociale forhold}

\subsection{Pengenes væesen}

Et er at vise at tingsliggørelsesteorien er forkert, noget andet at afsløre kilden til og den nøjere udfoldelse af denne fejltagelse. Dette sidste spørgsmål skal nu tages op.

Der er ingen tvivl om at det forskningsmæssige udgangspunkt for Marx's fetichismeteori er pengefetichismen, mens vare- og kapitalfetichismen først senere er kommet ind i billedet. En egentlig varefetichisme omtales ikke hos den unge Marx, hvorimod der ofte findes henvisninger til det fordrejede ved de tingslige penge, f.ex.:

»Pengenes vaesen er ... at den formidlende aktivitet eller bevægelse, den menneskelige, sociale akt, hvorigennem menneskenes produkter gensidigt kompletterer hinanden - fremmedgфres og bliver til egenskaben ved en materiel ting udenfor menneskene, nemlig pengene. (Marx: Aus den Exzerptheften, i: Marx/Engels: Studienausgabe 2, Frankfurt 1971, p. 247).

Marx vil udlede pengene af varen, og da han er overbevist om at pengene $n \varnothing d-$ vendigvis er tingslige, tvinges han til at indpode kimen til denne tingsligg ørelse i varen; deraf varefetichismen.

Marx er tilhænger af den såkaldte metallistiske pengeopfattelse, iflg. hvilken pengefunktionen nødvendigvis er forankret i reale varer $;{ }^{88}$ pengene henter deres værdi fra guldets fremstillingsomkostninger, målt i arbejde. Det alternative synspunkt har traditionelt været den såkaldte cartalistiske pengeteori $($ carta $=$ papir), der hævder at pengenes værdi eller købekraft til sit væsen er konventionel, - den bygger ikke på en særlig vares realværdi, men på gensidig tillid (jvf. citaterne af Samuelson og Friedman ovenfor).

Som nævnt hylder moderne borgerlig teori den sidstnævnte opfattelse, hvorfor Marx's tingsliggørelsesteori, qua teori om den borgerlig bevidsthed, er falsificeret. Det spørgsmål, der nu skal tages op, er imidlertid, hvilken pengeteori der faktisk er den rigtige.

I forrige århundrede var de fleste $\emptyset$ konomer (bl.a. Ricardo) enig med Marx; og grunden til at den metallistiske pengeteori således var relativt ukontroversiel var, at landenes pengesystemer var baseret på at pengesedlerne kunne indløses med ædelmetallerne. Forskellen mellem Marx og de andre økono-

8. At det netop er blevet guld og sølv beror derimod på forhold, især mineralogiske, der ligger udenfor politøkonomien: »Spørgsmålet om, hvorfor guld og sølv - og ikke andre varer - tjener som pengenes materiale, falder udenfor grænserne af det borgerlige system.« (Til Kritikken, pp. 128f/154). 
mer var 'blot', at Marx fandt det irrationelt og fordrejet at pengenes værdi og dermed de almene $\varnothing$ konomiske sammenhænge - bestemtes af noget i sig selv så ligegyldigt og tilfældigt som nye guldfund eller øget produktivitet ved guldproduktionen.

Tilsvarende er det ikke vanskeligt at henføre den moderne cartalistiske pengeteori til ophævelsen af guldindløseligheden; nok optræder der med mellemrum internationale guldkriser, men idag er det ikke svingningerne i guldets værdi, der påvirker pengesystemet, men den anden vej rundt.

Der er nu to tolkninger af denne udvikling. Marxister vil hævde, at ædelmetallernes dalende betydning er udtryk for en real mystificering af det borgerlige samfund; på samme måde som reallønnens stigning væsentligt over subsistensniveauet har tjent til at tilsløre udbytningen. Den aktuelle virkeligheds afvigelse fra 'Kapitalens' virkelighed er kort sagt en forfalskning af kapitalismen. Alternativt kan man mene - og det gør jeg - at pengene først i dette århundrede har udarbejdet sit væsen ved at afkaste sin metalliske iklædning; Marx har ret i at pengenes forankring $i$ et metal er en irrationalitet eller en mangel, - og netop derfor har det kapitalistiske system erstattet de metalliske puppepenge med de mere voksne immaterielle penge. De metalliske penge er et førborgerligt levn, som kapitalen endnu i forrige århundrede ikke havde overvundet; men Marx ophøjer i sin tingsliggørelsesteori dette arkaiske træk ved pengene til grundmodellen for fordrejningerne i det borgerlige samfund. ${ }^{9}$

Penge er ikke i sig selv tingslige; det er Marx himself, der tingsligg ør dem. I det følgende skal jeg søge at vise, at det samme gør sig gældende mht. de $\emptyset$ vrige grundkategorier i den marxske polit $ø$ konomi, abstrakt arbejde, værdi og brugsværdi.

\subsection{Abstrakt arbejde og værdi}

Kernen i tingsliggørelsesteorien er at de sociale forhold, således som de er inkarneret i det abstrakte arbejde og værdien, fremtræder fordrejet, nemlig tingsligt. Derfor må abstrakt arbejde og værdi være patenteret ikke-tingslige; Marx pointerer da også at værdien ikke indeholder 'ét atom naturstof', ligesom det fremhæves at abstrakt arbejde er at forstå som socialt nødvendig arbejdstid, og tiden er jo et immaterielt fænomen.

9. For en ordens skyld skal det nævnes, at cartalismens subjektivering af pengene ikke er eneste alternativ til metallismen; jeg mener selv at pengene til deres væsen er en immateriel, men særdeles objektiv social sammenhæng, men en nærmere diskussion heraf vil føre for vidt på dette sted. 
Hvis der smugles så meget som ét miligram naturstof ind i disse kategorier, kortsluttes hele teorien: En tingslig fremtrædelsesform er nu ikke længere en fordrejning og tilsløring af abstrakt arbejde/værdi, hvorfor tingsligg ørelsesteorien mister sin mening; alternativt kan man sige at hvis værdien forudsættes som tingslig, er det ingen kunst at udlede nødvendigheden af en tingslig værdiform, dvs. den teoretiske opgave er på forhånd løst. Mange centrale udtalelser hos Marx effektuerer imidlertid netop denne kortslutning.

Det abstrakte arbejde bestemmes som 'produktivt forbrug / Verausgabung/ af menneskelig hjerne, muskel, nerve, hånd osv.' (K.I., p. 58/139), som 'forbrug af menneskelig arbejdskraft i fysiologisk forstand.' (K.I., p. 61/142, jvf. også K.I., p. 85/170). ${ }^{10}$ Det abstrakte arbejde naturaliseres således. Tilsvarende tingsliggør Marx vaerdien:

»En brugsværdi eller et gode har altså kun en værdi, fordi abstrakt menneskeligt arbejde er genstandsgjort /vergegenständlicht/ eller materialiseret i den.« (K.I., p. 53/132).

Værdien begribes her éntydigt som materiel, tingslig eller genstandsagtig. Som nævnt kan der hos Marx også findes belæg for at værdien er helt immateriel, men i sit billedsprog gør han uvægerligt værdien tingslig: den er 'stivnet' arbejde, en 'gelé' eller 'krystaller' (K.I., p. 52/131).

Nok så væsentligt er det imidlertid, at Marx analyserer disse grundbegreber v.hj.a. fysiske kategorier. Efterhånden som fremstillingen skrider frem, glemmes de oprindelige udsagn om værdien som et uhåndgribeligt socialt fænomen, og den fremstår mere éntydigt som tingslig/naturlig. Arbejdet er 'årsag' eller 'kilde' til værdi, og senere viser det sig at merværdi 'produceres' og værdi (i skikkelse af konstant kapital) 'overføres'; men hvis merværdi og værdi er ikke-tingslige sociale sammenhænge, er disse formuleringer lige så irrationelle som hvis man talte om at monarkiet spadserede en tur:

10. Denne naturalisering af det abstrakte arbejde skaber iøvrigt et alvorligt problem for arbejdsværdilæren qua pristeori. Denne udsiger at varerne udveksles i forhold til den tid, det gennemsnitligt har taget at producere dem; men hvis abstrakt arbejde ikke skal forstås som tid, men fysiologisk, må det betyde at det skal måles i en fysiologisk energienhed såsom kalorier. Og da værdien måles i abstrakt arbejde, bliver kalorier dermed det ultimative værdimål. Da én times skomagerarbejde forbruger mindre 'hjerne, muskel osv.' end én times jord- og betonarbejde, skaber den mindre vardi; kalorier er det overordnede værdimål, og det er kun i det særlige tilfælde, hvor alt arbejde er af samme intensitet, at denne målestok falder sammen med tiden. At Marx forudsatter en ensartet intensitet i vare- og pengeanalysen, ændrer ikke dette forhold; der må være en sammenhæng mellem målestokken og karakteren af det, der skal måles: hvis en fysiker bestemmer et fænomen som værende af magnetisk natur, kan han ikke derefter måle det, som om der var tale om en helt anden kraft. 
det er Margrethe, der kan spadsere en tur, og det er fysiske fænomener, der kan 'produceres' og 'overføres'. Men Marx behandler altså de sociale relationer, som var de tingslige; de begribes i de fysiske fænomeners logiske kategori, nemlig kausaliteten, ikke i de praktiske interessers teleologiske kategorier.

Forestillingen om værdien og merværdien som tingslig kommer måske klarest frem i forbindelse med Marx's opfattelse af kapitalkonkurrencen: Først skaber arbejderne merværdien i produktionsprocessen, dernaest fordeles den af konkurrencen på de forskellige kapitaler i overensstemmelse med disses størrelse; men det ser ud som om profitten kommer fra distributionen og som om den gennemsnitlige profitrates højde bestemmes af konkurrencen, dvs. konkurrencen indbegriber en tilsløring og fordrejning af de virkelige sammenhænge. Argumentet for denne teori er, at konkurrencens fordeling af profitten forudsætter, at profitten i forvejen er der; konkurrencen kan kun fordele det allerede skabte, den kan aldrig selv skabe noget. Denne tankegang antager imidlertid stiltiende at merværdi og profit er fysiske fænomener, der er produceret af fysiologisk arbejde: det er indlysende at produktionen af stole går forud for deres fordeling, og det er indlysende at denne fordeling ikke kan skabe stolene.

Det er i vidt omfang interessen $\mathrm{i}$ at formulere en udbytningsteori, der driver Marx til at tingsliggøre/naturalisere sine grundbegreber. Merværditeoriens agitatoriske kraft hviler på, at kapitalen som en vampyr udsuger arbejdet; merværdien må være inkarnationen af arbejdernes blod, sved og tårer, dvs. af deres virkelige fysiske arbejde. Hvis merværdien og merarbejdet i stedet er sociale relationer, der er abstrakte netop i kraft af abstraktionen fra alle naturlige bestemmelser, bliver også udbytningen en luftig abstraktion, som man skal være magister i filosofi for at kunne oprøres over.

\subsection{Brugsværdi og værdiform}

Som nævnt (jvf. 2) bestemmes bytteforholdet umiddelbart af kampen mellem modstående interesser, - frakkernes brugsværdi for skomageren og skoenes brugsværdi for skrædderen.

Hvordan kan Marx da komme frem til at værdien fremtræder tingsligt, at byttet lader de sociale sammenhænge fremstå som var de udsprunget af varekroppens tingslige egenskaber? Svaret giver næsten sig selv: Marx forvandler selv brugsværdien til en ting, nemlig ved at skære brugsværdiens behovsside bort. 
Dette kommer allerede til udtryk i den abstrakte bestemmelse af brugsværdien, som Marx giver ved begyndelsen af fremstillingen, tydeligst formuleret $\mathrm{i}$ Til Kritikken:

»Varen er i første omgang, i de engelske økonomers formulering, 'en eller anden ting, nødvendig, nyttig eller behagelig for livet', genstand for menneskelige behov, livsmiddel /lebensmittel/ i ordets videste betydning.« (Til kritikken, p. 15/19).

Derfor er brugsværdien en relation mellem ting og behov, betinget og bestemt af begge faktorer; dette dementeres imidlertid straks i næste sætning:

»Denne varens existens /Dasein/ som brugsværdi og dens naturlige håndgribelige existens /Existenz/ falder sammen. ... Den samme brugsvardi kan benyttes forskelligt. Summen af dens mulige nytteanvendelser er imidlertid sammenfattet i dens existens /Dasein/ som ting med bestemte egenskaber.« (ibid; mine fremhævelser).

Dette kan ikke være rigtigt. Eftersom den samme ting kan benyttes forskelligt, altså kan tilfredsstille forskelligartede behov, har den forskellige brugsvardier; f.ex. kan en pibe bruges til at ryge på og til, af et barn, at lege med, ${ }^{11}$ men hvordan 'gribe med hånden' om disse nytteanvendelser? Og hvorfor skulle en 'summering' af tingens relationer til omverdenen (de forskellige behov) resultere i den relationsløse 'ting med bestemte egenskaber'?

\section{I 'Kapitalen' hedder det:}

»En tings nytte gør den til brugsværdi. Men denne nytte svæver ikke i luften. Den er betinget af varekroppens egenskaber og existerer derfor ikke uafhængigt af denne. Varekroppen selv, f.ex. jern, hvede, diamant etc., er derfor en brugsvaerdi.« (K.I., p. 50/129; mine fremhævelser).

Den første sætning definerer brugsværdien klart: den er ikke en ting, men en ting, der har nytte; dernæst slutter Marx fra det forhold, at tingens brugsværdi forudsatter tingen, til påstanden om at brugsværdien er tingen. ${ }^{12}$ Man kunne lige så godt - eller rettere: dårligt - sige at fordi brugsværdien forudsatter behov, er brugsværdien behov.

11. Exemplet er relevant, eftersom det her drejer sig om brugsværdiens mest almene eller abstrakte egenskaber, hvori bl.a. det blot 'behagelige' er indbegrebet.

12. Jvf. også at det lidt senere hedder: »Brugsværdier danner rigdommens stoflige indhold, ...« (K.I., p. 50/129; min fremhævelse). - Hvor Marx i 2. udgaven af Kapitalen søger at give en realbegrundelse for sin tingsliggørelse af brugsværdien ('nytten svæver ikke i luften etc.'), hedder det i 1. udgaven: »En tings nytte for den menneskelige existens gør den til brugsvardi. For kortheds skyld /abkürzend/ kalder vi selve denne ting eller varekroppen, f.ex. jern, hvede, diamanter etc., for brugsvaerdi, gode, artikel.« (1. udg., p. 216/31 (refererer til hhv. den tyske Fischer Taschenbuch udg. og den danske Modtryk udg.); Marx’s fremhævelser); her fremstår tingsliggørelsen altså som en ret sproglig forenkling. 
Brugsværdien er ikke ting og den er ikke behov: Den er den umiddelbare praktiske relation mellem ting og behov, og derfor betinget og bestemt af begge faktorer. Det indebærer bl.a. at jo større behovet er, jo større er brugsværdien; hvis man som Marx lader brugsværdien være sammenfaldende med 'varekroppen', må man hævde at ét kg hvede til alle tider og for alle mennesker har (er) den samme brugsværdi, thi varekroppen fortæller ikke noget om, hvorvidt folk er mætte eller ved at $d \varnothing$ af sult.

I Marx's hænder skrumper brugsværdien altså ind til en ting, ved at skære relationen til behovene bort tingsliggør han brugsværdien. Dette er ikke en tilfældig analysefejl, men den nødvendige teoretiske forberedelse for at kunne fremstille vareformen som tingslig værdiform. »Bytteværdien fremtræder i første omgang som det kvantitative forhold, hvori brugsværdier udveksles«, skriver Marx, jvf. ovenfor; det er denne umiddelbare fremtrædelsesform, som værdiformsanalysen skal forklare, - og som den skal udlægge som tingslig; det er klart at den første forudsætning herfor er, at forholdet mellem brugsværdierne forvandles til et forhold mellem ting. ${ }^{13}$

I hele 1. kapitel af 'Kapitalen' betyder brugsværdien 'ting' ${ }^{14}$ eller naturalform; først i 2. kapitel (om udvekslingsprocessen) genvinder begrebet den betydning, som det oprindelig har (som vi har set: også hos Marx) ved at behovene igen kobles til tingen.

På denne baggrund er det ikke svært at bevise tingsliggørelses- eller fetichismeteorien:

»Brugsvardi bliver til fremtrædelsesform for sin modsætning, værdien. Varens naturalform bliver til værdiform.«(K.I., pp. 70f/153; mine fremhævelser).

Denne identificering af brugsværdi og naturalform (ting) er grunden til, at det for Marx fremtræder som om

»frakken har sin ækvivalentform, dvs. sin egenskab af at være umiddelbart udvekslelig, fra naturen, - i lige så høj grad som sin egenskab at være tung eller varm.«(K.I., p. 72/155; ækvivalentformen er en værdiform).

13. Dette sker allerede i en note til det netop angivne citat, hvor Marx citerer Le Trosne: »Værdien består i det bytteforhold, som findes mellem én ting og en anden...« (K.I., p. 50/129).

14. Jvf. f.ex.: »Brugsværdierne frakke, lærred osv. - kort: varekroppene - er forbindelsen af 2 elementer, naturstof og arbejde.« (K.I., p. 57/137); det tredje element, behovene, mangler. Dette indebærer iøvrigt at det marxske opg ør med enhver behovsteori, herunder den subjektive, er overstået før det er begyndt, thi når Marx i forvejen har abstraheret fra behovene, bliver kommensurabilitetsargumentets abstraktion fra brugsværdierne blot en abstraktion fra tingene, dvs. et slag i luften, set fra behovsteoriens synsvinkel. 


\section{Dette kan kun hævdes, fordi brugsværdiens behovsside er elimineret. ${ }^{15}$}

15. I 'Til rekonstruktionen af kritikken af den politiske økonomis omfangslogiske status' (Modtryk 1973) kritiserer Hans-Jørgen Schanz Marx's begrebsbestemmelse. Efter at have citeret Marx: »Brugsværdi bliver til fremtrædelsesform for sin modsætning, værdi«, skriver han: »Egentlig skulle det have heddet, at materialitetsformen bliver til Ercheinungsform for sin modsætning, værdien, fordi brugsværdien... ikke er nogen form, men en egenskab ved en materialitetsform i relation til et menneskeligt behov.« (p. 103). Schanz insisterer altså på, at eftersom brugsværdien indbegriber behov har den ikke noget at gøre i værdiformsanalysen; for så vidt er han mere konsekvent end Marx. Specielt pointerer Schanz at den marxske pengeform - penge som ting - forudsætter at der er tale om naturalformen eller materialitetsformen, og ikke om guld som brugsværdi: »Idet pengeformen er værdiformens hypostase, og værdiformen altid qua værdiform må være usurpationen af en materialitetsform, kan vi nu se nødvendigheden af distinktionen mellem materialitetsform og brugsværdi. Hvis materialitetsformen ikke havde en irreduktibel status overfor det menneskelige behovs gøren materialitetsformen til bærer af en bestemt (og ikke hypostaserbar) brugsværdiegenskab, så ville værdiformens hypostasering være en umulighed. Pengeformen derfor også.« (p. 115); sammenlign p. 120: »Det er kun som også naturstof, at guld kan blive penge, ...« Det er her temmelig klart, at det er forestillingen om de tingslige penge, der strukturerer de mere abstrakte begrebsbestemmelser. 


\section{STATEN I DET KAPITALISTISKE SAMFUND - EN INTRODUKTION.}

\section{Genoptryk af artikler fra Kurasje. 72 sider, 25,- kr.}

I den diskussion af staten i det kapitalistiske samfund, som startede i Danmark i begyndelsen af 70'erne, indtog Elmar Altvaters artikel »Om nogle problemer ved statsinterventionismen « en central plads. I diskussionens forløb overså mange, både »tilhængere « og »modstandere «, hvad artiklens centrale problemstilling var. Når man dengang lagde hovedvægten på Altvarters fors $\emptyset \mathrm{g}$ på at bestemme centrale statsfunktioner, overså man, at artiklen primært er en kritik af den keynesianske blandings $\varnothing$ konomi - af denne $\varnothing$ konomiske poltisks grænser og dens midlers binding til cirkulationssfæren. Ligeledes påviser artiklen hvorledes de borgerlige $\varnothing$ konomer og "politikmagere « er fikseret i disse sammenhænge og ikke kan begribe de egentlige akkumulationsproblemer for kapitalen.

Og disse kritikpunkter kan næppe siges at være blevet gjort overflødige. De sidste 5 års krise og desperate statslige løsningsfors $\emptyset \mathrm{g}$ har tværtimod gjort det endnu mere nødvendigt for socialister at fastholde en konsekvent kritik af de statslige kriseløsninger - lige meget hvorfra de så kommer!

I den forstand er artiklerne i denne bog lige så aktuelle som da de første gang udkom og er stadig de bedste introduktioner til statsdiskussionen. 